\title{
Distributional ecology of shallow southwestern Beaufort Sea (Arctic Ocean) bivalve Mollusca
}

\author{
Andrew G. Carey, Jr., Paul H. Scott* and Keith R. Walters** \\ College of Oceanography, Oregon State University, Corvallis, Oregon 97331, USA
}

\begin{abstract}
Benthic macrofauna was sampled off the northern coast of Alaska to determine whether the shallow-water Arctic sublittoral fauna is uniformly distributed among stations as suggested by MacGinitie (1955), or whether it is distributed in ecological assemblages. During the study 5,000 living individuals of bivalve molluscs were collected of 31 species. Analysis revealed that there are no general patterns of total numerical density, species richness, or species composition from 5 to $25 \mathrm{~m}$ depth across the southwestern Beaufort Sea. There was, however, a greater similarity of bivalve faunal composition among stations than would be expected by stochastic processes alone. An analysis of feeding types demonstrated that there is a tendency toward functional groupings of suspension and deposit feeders. Sedimentary features (interacting with depth) appear to influence the bivalve fauna: more deposit feeding bivalves are associated with finer sediments at the deeper stations. The relatively high species richness in shallow Arctic waters more closely resembles bivalve assemblages in protected temperate environments than it does those of the open coast. The lack of major disturbance of sediments by waves in the ice-dominated Beaufort Sea appears to be ecologically important.
\end{abstract}

\section{INTRODUCTION}

Until the last decade the molluscan fauna of the Beaufort Sea was little studied. The few early works were mainly taxonomic: Dall (1919) reported on the molluscs from the Canadian Arctic Expedition (1913-1918). George MacGinitie (1955) and Nettie MacGinitie (1959) published on the molluscs in the Chukchi Sea-Beaufort Sea boundary region in the vicinity of Point Barrow, Alaska. Several reports were later published in connection with assessment of the offshore environment prior to oil development (Hülsemann, 1962; Wacasey, 1975; Carey and Ruff, 1977; Wagner, 1977). The most complete description of the bivalve fauna of the southwest Beaufort Sea was published by Bernard (1979). The present paper describes the coastal bivalve fauna ( 5 to $25 \mathrm{~m}$ depth) in the southwestern Beaufort Sea and for the first time reports patterns in numerical density, species diversity, compositional similarity, and feeding type found there.

\footnotetext{
- Present address: Department of Invertebrate Zoology, Santa Barbara Museum of Natural History, Santa Barbara, California 93105, USA

- Present address: Department of Biology, University of South Florida, Tampa, Florida 33620, USA
}

The study region lies on the inner Alaskan shelf seaward of the barrier islands (Fig. 1). The shallow area is subject to intense seasonality with major changes in isolation, ice cover, salinity, temperature, turbulence, turbidity, and sea ice gouging of the sediments (Sharma, 1979). Ice generally is present in the marginal ice zone along the southern boundaries of the Arctic Ocean from late September through early June; it attains a maximum thickness of 1.5 to $2.0 \mathrm{~m}$ (Kovacs and Mellor, 1974). The freezing and thawing sea ice cover and run-off from adjacent rivers during the summer melt season significantly affect the coastal water mass characteristics. They decrease the salinity to as deep as $20 \mathrm{~m}$, the upper limit of the pycnocline (Sharma, 1979).

Dense pack ice in the southwestern Beaufort Sea prevents waves and wave-induced turbulence in winter (Squire and Moore, 1980). In summer the scattered, open pack in the marginal sea ice zone and the limited fetch of open water dampens the generation of significant waves. Erosive wind-driven currents on the inner shelf are brief (Wiseman et al., 1974), and are generally westward-flowing on the inner shelf during the summer open-water season (Barnes and Reimnitz, 1974; Mountain, 1974; Short et al., 1974). Tidal amplitude is small and tidal currents are weak, though 
sea level variations caused by storms occasionally produce significant bottom currents (Matthews, 1971, 1980).

This shallow area is subject to seasonal variations in ice gouging of the sea floor. The deep keels of icepressure ridges impinge on the bottom and move sediments creating patchy distributions (Barnes and Reimnitz, 1974; Reimnitz and Barnes, 1974). The highest frequency of scouring occurs in water depths of 20 to 40 in (Barnes et al., 1978).

MacGinitie's (1955) suggestion that the Beaufort Sea continental shelf was an homogenous 'unit environment' with benthic species uniformly distributed throughout the region has never been critically examined. Our objective was to determine if the bivalve mollusc fauna is evenly distributed throughout the coastal zone, or whether the faunal distributions are correlated with depth, sediment type or other environmental characteristics.

\section{MATERIALS AND METHODS}

Benthic macrofauna and sediments were sampled with a $0.1 \mathrm{~m}^{2}$ Smith-McIntyre bottom grab (Smith and McIntyre, 1954) aboard the R/V 'Alumiak' and the USCGC 'Glacier' during August and September 1976. The sampling strategy was designed to determine possible large-scale faunal patterns related to depth and longitude on the inner continental shelf. The transects were normal to the coastline and located equidistant along the shelf at Point Barrow (BRB), Pitt Point (PPB), Pingok Island (PIB), Narwhal Island (NIB), and Barter Island (BAB) (Fig. 1). Five biological grab samples were collected from all stations, which were located at 5 depth intervals between 5 and $25 \mathrm{~m}$ on each transect (Table 1). Three stations (PIB 20, PIB 25, NIB 20) could not be occupied by either vessel because of heavy sea ice. The full sample set was 110 quantitative samples from 22 stations. Subsamples from an additional grab were generally taken at each station and analysed by hydrometer for particle size and by LECO induction furnace and carbon determinator for organic carbon.

On board ship the grab samples were measured for volume, and only those with a minimum of $5.5 \mathrm{l}$ of sediment and an unwashed appearance were retained for quantitative analysis. The sediment was screened through a cascading multiple sieve system (Carey et al., unpubl.) with a minimum aperture size of $0.42 \mathrm{~mm}$, and the retained samples were preserved in $10 \%$ formalin neutralized with sodium borate. In the laboratory, the samples were stained with rose bengal and the large macrofauna ( $>1.0 \mathrm{~mm}$ ) were picked from the sieved material under a dissecting microscope. The bivalves were identified by $\mathrm{P}$. H. Scott.

\section{RESULTS}

\section{Density and species richness}

A total of 5,000 bivalve individuals representing 31 species were collected (Table 2). The bivalves comprised $19.8 \%$ of the numbers of benthic macrofauna $>1.0 \mathrm{~mm}$. Most of the numerically dominant species were found at all depths with 2 notable exceptions. Boreacola vadosa, the most abundant species, was collected only inshore at depths of 5, 10, and $15 \mathrm{~m} ; 98 \%$ of the individuals were recorded from 1 station (PPB 05). Cyrtodaria kurriana was found exclusively at $5 \mathrm{~m}$. This limited distribution of C. kurriana concurs

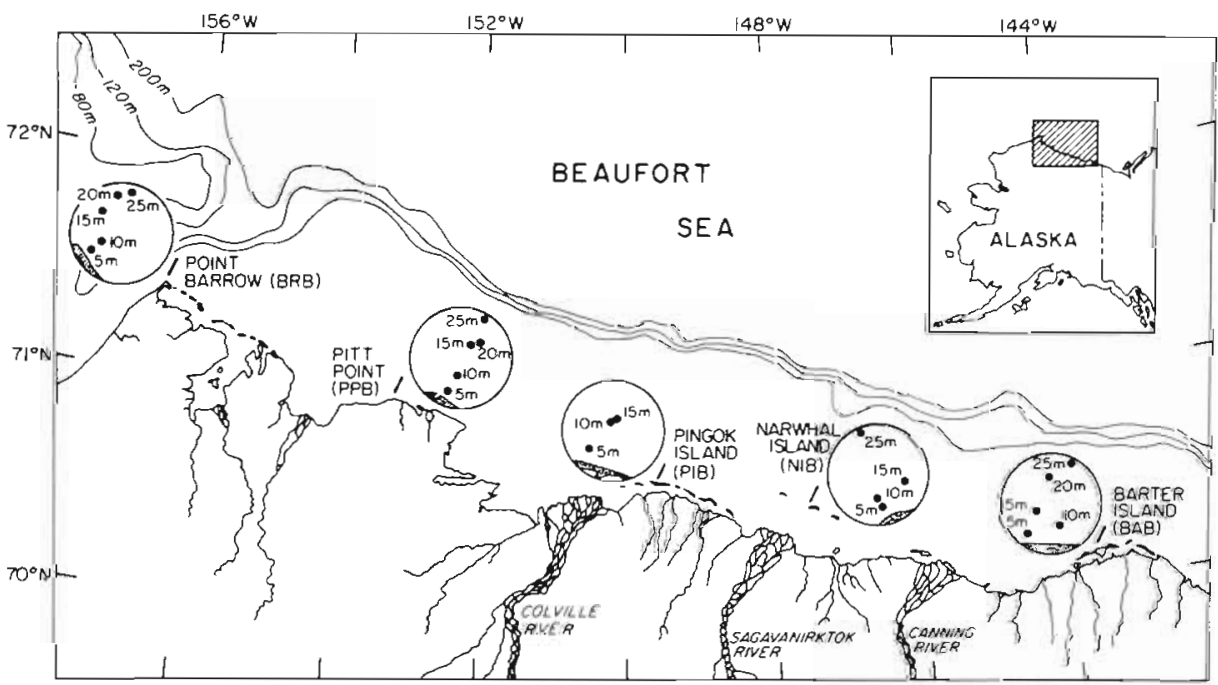

Fig. 1. Location map of the northern coast of Alaska showing the station transects in southwestern Beaufort Sea and individual station locations (circle insets). Circle inset diamater: $\mathrm{BRB}$ and $\mathrm{PIB}=10.5$ $\mathrm{km} ; \mathrm{PPB}=29.8 \mathrm{~km}, \mathrm{NIB}$ and $\mathrm{BAB}=6.4 \mathrm{~km}$ 
Table 1. Environmental parameters, bivalve abundance and bivalve feeding types in the Beaufort Sea coastal zone

\begin{tabular}{|c|c|c|c|c|c|c|c|c|c|c|c|}
\hline \multirow[b]{2}{*}{ Transect } & \multirow[b]{2}{*}{$\begin{array}{l}\text { Depth } \\
\text { (m) }\end{array}$} & \multirow[b]{2}{*}{$\begin{array}{l}\text { Sediment } \\
\text { type }\end{array}$} & \multicolumn{5}{|c|}{ Environment } & \multicolumn{4}{|c|}{ Bivalve Fauna } \\
\hline & & & $\begin{array}{c}\text { Gravel } \\
\%\end{array}$ & $\begin{array}{l}\text { Sand } \\
\%\end{array}$ & $\begin{array}{l}\text { Silt } \\
\%\end{array}$ & $\underset{\%}{\text { Clay }}$ & $\begin{array}{l}\% \text { Or- } \\
\text { ganic } \\
\text { carbon }\end{array}$ & $\begin{array}{l}\text { \# of } \\
\text { species }\end{array}$ & $\begin{array}{l}\# \text { of } \\
\text { indi- } \\
\text { viduals }\end{array}$ & $\begin{array}{l}\% \text { Sus- } \\
\text { pension } \\
\text { feeders }\end{array}$ & $\begin{array}{l}\% \text { De- } \\
\text { posit } \\
\text { feeders }\end{array}$ \\
\hline \multirow{5}{*}{$\begin{array}{l}\text { Pt. Barrow } \\
\text { (BRB) }\end{array}$} & 5 & Sand & 1.4 & 96.6 & 1.1 & 0.9 & 0.10 & 4 & 44 & 100 & 0 \\
\hline & 10 & Silty sand. & - & - & - & - & - & 11 & 215 & 88 & 12 \\
\hline & 15 & Sandy silt ${ }^{\circ}$ & - & - & - & - & - & 2 & 5 & 20 & 80 \\
\hline & 20 & Sandy silt. & - & - & - & - & - & 3 & 22 & 45 & 55 \\
\hline & 25 & Sandy silt ${ }^{\circ}$ & 0.0 & 38.0 & 39.2 & 22.8 & 0.47 & 5 & 58 & 14 & 86 \\
\hline \multirow{5}{*}{$\begin{array}{l}\text { Pitt Point } \\
\text { (PBB) }\end{array}$} & 5 & Silty sand & 0.0 & 65.8 & 26.3 & 7.8 & 0.81 & 14 & 2454 & 94 & 6 \\
\hline & 10 & Silty sand & 0.0 & 71.0 & 19.2 & 9.8 & 0.17 & 10 & 243 & 60 & 40 \\
\hline & 15 & Clayey silt & 0.0 & 8.1 & 51.2 & 40.7 & 1.0 & 4 & 40 & 2 & 98 \\
\hline & 20 & Clayey silt ${ }^{\circ}$ & - & - & - & - & - & 4 & 98 & 1 & 99 \\
\hline & 25 & Clayey silt & 0.0 & 4.3 & 49.1 & 46.6 & 0.78 & 10 & 217 & 4 & 96 \\
\hline \multirow{3}{*}{$\begin{array}{l}\text { Pingok Island } \\
\text { (PIB) }\end{array}$} & 5 & Sand & 0.0 & 73.2 & 16.9 & 9.9 & 0.09 & 2 & 4 & 0 & 100 \\
\hline & 10 & Silty sand & 0.0 & 53.3 & 38.8 & 7.9 & 0.03 & 11 & 422 & 54 & 46 \\
\hline & 15 & Sandy silt ${ }^{\circ}$ & - & - & - & - & - & 12 & 215 & 73 & 27 \\
\hline \multirow{4}{*}{$\begin{array}{l}\text { Narwhal Island } \\
\text { (NIB) }\end{array}$} & 5 & Gravel-sand & 15.9 & 71.8 & 6.4 & 5.9 & $<0.01$ & 1 & 1 & 100 & 0 \\
\hline & 10 & Sand & 0.3 & 85.8 & 7.0 & 6.9 & 0.08 & 7 & 53 & 92 & 8 \\
\hline & 15 & Gravel-sand & 27.0 & 54.0 & 10.3 & 8.7 & $<0.01$ & 12 & 35 & 66 & 34 \\
\hline & 25 & Sand-silt-clay & 9.6 & 27.9 & 27.7 & 34.8 & 0.15 & 12 & 36 & 31 & 69 \\
\hline \multirow{5}{*}{$\begin{array}{l}\text { Barter Island } \\
\text { (BAB) }\end{array}$} & 5 & Sand-silt-clay & 0.0 & 76.3 & 18.1 & 5.6 & $<0.01$ & 5 & 19 & 74 & 26 \\
\hline & 10 & Sand & 0.0 & 92.5 & 4.5 & 3.0 & 0.03 & 7 & 97 & 60 & 40 \\
\hline & 15 & Silty sand & 0.0 & 64.8 & 22.5 & 12.7 & 0.17 & 10 & 378 & 66 & 24 \\
\hline & 20 & Silty sand & 0.0 & 47.0 & 25.7 & 27.3 & 0.31 & 13 & 245 & 73 & 27 \\
\hline & 25 & Sand-silt-clay & 0.0 & 37.6 & 24.8 & 37.6 & 0.34 & 8 & 99 & 33 & 67 \\
\hline
\end{tabular}

with previous reports by Wagner (1977) and Bernard (1979). Sixty-four \% of the stations contained fewer than 200 bivalve individuals $\mathrm{m}^{-2}$. Total species numbers per station were generally low and varied from a high of 14 (PPB 05) to a low of 1 species per station at NIB 05 (Table 1).

Small-scale spatial variation in bivalve density was evident between grabs. Frequently the variation spanned an order of magnitude in numbers of individuals per grab at a station. Large-scale differences exist between stations with a range of 1 to 2,454 individuals per station. Since the Smith-McIntyre grab is not an effective sampling device with which to elucidate small-scale patterns of benthic distribution (Jumars, 1976), differences between grabs might easily represent sampling bias. For this reason the numbers of individuals per grab at each station were combined, and the station data were analysed to determine whether differences in total abundance correlated with depth or with transect (longitude). A 2-way analysis of variance for the log-transformed number of bivalves indicates no significant difference either by depth $(\mathrm{F}=$ $0.793, \mathrm{P}=0.55)$ or by transect $(\mathrm{F}=1.654, \mathrm{P}=0.22)$. The test is conservative because the interaction and error terms were combined.

The 5 grabs per station were again combined in an analysis to consider large-scale variation in species numbers. To include the relation between numbers of individuals sampled and the number of species, expected species numbers [E(Sn)] were calculated according to Hurlbert (1971) along with their associated variance (Heck et al., 1975). The distribution of individuals per species for each of the 22 stations was used in calculating $\mathrm{E}(\mathrm{Sn}) ; 30$ was chosen as the equivalent number of individuals ( $n$ ) at which to compare species richness because all but 4 of the stations (BRB 15, BRB 20, PIB 05, NIB 05) then could be included in the analysis. Although the underlying distribution of species and individuals can affect the calculation of $\mathrm{E}(\mathrm{Sn})$ and the resulting comparisons (Peet, 1974), examination of expected species curves suggests that $E\left(S_{30}\right)$ is a valid measure of richness of the fauna. Twoway ANOVA with combined error and interaction terms indicate no significant difference in species richness either by depth $(F=1.339, P=0.31)$ or transect ( $F$ $=2.301, \mathrm{P}=0.11$ ). No significant large-scale variations in the numbers of species were apparent for the area studied.

\section{Compositional similarity}

Lack of systematic variation in the total number of bivalve individuals as in the number of species does not preclude marked differences in species composition across the region. Compositional similarity was analysed by (1) numerical classification with a similar- 
Table 2. Distribution of bivalve species by depth and feeding type ( $\mathrm{S}=$ suspension feeder, $\mathrm{D}=$ deposit feeder). Species are ordered by increasing depth. Those taxa which clustered as one group at a Jaccard similarity greater than 0.5 are indicated by ${ }^{*}$ Taxonomic nomenclature follows Bernard (1979)

\begin{tabular}{|c|c|c|c|c|c|c|c|}
\hline \multirow[t]{2}{*}{ Species } & \multirow{2}{*}{$\begin{array}{l}\text { Feeding } \\
\text { type }\end{array}$} & \multicolumn{5}{|c|}{ Mean number $\mathrm{m}^{-2}$ at depth $(\mathrm{m})$} & \multirow{2}{*}{$\begin{array}{l}\text { Total number } \\
\text { collected }\end{array}$} \\
\hline & & 05 & 10 & 15 & 20 & 25 & \\
\hline -Axinopsida orbiculata & $\mathrm{S}$ & 91 & 146 & 80 & 106 & 1 & 956 \\
\hline - Portlandia arctica & $\mathrm{D}$ & 14 & 104 & 45 & 84 & 60 & 774 \\
\hline - Liocyma fluctuosa & $\mathrm{s}$ & 130 & 87 & 46 & & $<1$ & 659 \\
\hline - Macoma calcarea & $\mathrm{D}$ & 49 & 22 & 27 & 11 & 29 & 313 \\
\hline - Arctinula greenlandica & $\mathrm{s}$ & $<1$ & 3 & 8 & 9 & 15 & 89 \\
\hline - Pandora glacialis & $\mathrm{s}$ & $<1$ & 3 & 13 & 1 & 1 & 49 \\
\hline Cyrtodaria kurriana & $\mathrm{s}$ & 63 & & & & & 157 \\
\hline Nuculana minuta & D & $<1$ & & & & & 3 \\
\hline Cyclocardia crebricostata & $\mathrm{S}$ & $<1$ & & & & & 2 \\
\hline Mysella planata & $\mathrm{S}$ & $<1$ & 1 & & & & 7 \\
\hline Hiatella arctica & $\mathrm{S}$ & $<1$ & $<1$ & & & 1 & 9 \\
\hline - Astarte montagui & $\mathrm{S}$ & 1 & & 32 & & & 87 \\
\hline Boreacola vadosa & $\mathrm{S}$ & 640 & 15 & $<1$ & & & 1640 \\
\hline Serripes groenlandicus & $\mathrm{s}$ & 17 & 5 & $<1$ & & & 57 \\
\hline - Thracia devexa & $\mathrm{S}$ & $<1$ & & 1 & & & 7 \\
\hline Yoldia hyperborea & $\mathrm{D}$ & & $<1$ & & & & 2 \\
\hline Yoldia myalis & $\mathrm{D}$ & & $<1$ & & & $<1$ & 6 \\
\hline Portlandia sp. A & $\bar{D}$ & & $<1$ & 1 & & & 8 \\
\hline Lyonsia arenosa & $\mathrm{S}$ & & 2 & 5 & & & 18 \\
\hline - Macoma inflata & $\mathrm{D}$ & & $<1$ & 1 & & & 8 \\
\hline - Macoma moesta & $\mathrm{D}$ & & 9 & 3 & & 3 & 58 \\
\hline - Nucula belloti & $\mathrm{D}$ & & $<1$ & $<1$ & 4 & 5 & 37 \\
\hline Mya pseudoarenaria & $\mathrm{S}$ & & 5 & $<1$ & 1 & $<1$ & 18 \\
\hline - Crenella decussata & $\mathrm{s}$ & & & $<1$ & $<1$ & & 3 \\
\hline Nuculana radiata & $\mathrm{D}$ & & & $<1$ & $<1$ & 1 & 7 \\
\hline Portlandia frigida & $\mathrm{D}$ & & & $<1$ & $<1$ & $<1$ & 4 \\
\hline Macoma loveni & $\mathrm{D}$ & & & $<1$ & $<1$ & $<1$ & 3 \\
\hline Nuculana pernula & $D$ & & & & $<1$ & 1 & 6 \\
\hline Portlandia lenticula & $\mathrm{D}$ & & & & $<1$ & 2 & 8 \\
\hline Mysella tumida & $\mathrm{S}$ & & & & & $<1$ & 1 \\
\hline Thracia myopsis & $\mathrm{S}$ & & & & & 1 & 4 \\
\hline Number of species & & 15 & 18 & 20 & 14 & 18 & 31 \\
\hline Number of individuals collected & & 2,522 & 1,030 & 673 & 365 & 410 & 5,000 \\
\hline Number of stations & & 5 & 5 & 5 & 3 & 4 & 22 \\
\hline
\end{tabular}

ity analysis and clustering methodology; (2) an analysis of expected taxa shared derived from a probabilistic hypothesis. Species groups were studied by these fundamentally different approaches to determine if distinct bivalve assemblages were distributed either by transect (longitudinally) or by station across the narrow environmental gradient, and to contrast the two statistical techniques.

\section{Numerical classification}

Similarities between all pairwise station and species comparisons were calculated using Jaccard's (1908) index. Similarity values were then clustered by a single-linkage algorithm (Anderberg, 1973). The one major species group that clustered at a Jaccard similarity greater than 0.5 is indicated in Table 2 . The stationby-station comparison based on species composition is displayed as a dendrogram (Fig. 2).

In the species by species comparisons 1 group of 12 bivalve species occurred with similarities greater than
0.5 ; it appears to represent the numerically abundant species in the study area (Table 2). Upon inspection of feeding type and depth distributions (Table 2), no biologically meaningful explanations can be deduced for this statistically-derived large species group. Five stations (NIB 10, PPB 10, PIB 10, BAB 15, BAB 10) at shallow depths and 2 (BAB25 and BAB20) in deeper water clustered as 2 groups, indicating a partial relationship with depth. However, no other depth-related groups were present with Jaccard similarities greater than 0.5 . These results may indicate that the sample size and/or the range of environmental conditions were not large enough to elucidate species distributions by depth. However, no general patterns that included the majority of either species or stations were indicated by this technique.

The difficulty with the above procedure, and with the use of most similarity indices and clustering techniques has been the lack of a null hypothesis against which results may be tested (Connor and Simberloff, 1978; Raup and Crick, 1979). For the Beaufort Sea bivalves, groupings of species or stations must be 
Fig. 2. Single linkage clustering of Jaccard station similarities for bivalve molluscs in SW Beaufort Sea

judged on whether they represent real differences in mollusc distributions by arbitrary criteria, i.e. Jaccard similarities greater than 0.5. Recognition of these groups rests on the differences in the Jaccard or other indices and assumes an objective meaning, but this cannot be demonstrated (Connor and Simberloff, 1978; Simberloff and Connor, 1980).

\section{Expected taxa shared}

The arbitrary nature of similaity indices and clustering strategies has led to various alternative approaches for viewing compositional similarity, many based on a probabilistic hypothesis (Harper, 1978; Simberloff, 1978; Raup and Crick, 1979). A null hypothesis was chosen to test whether the bivalve distributions in the Beaufort Sea conformed to a model representing stochastic persistence and random dispersion of species. Null Hypothesis I of Connor and Simberloff (1978) states that the observed number of species in common between 2 stations is not more than would be expected if the species composition was determined by randomly assigning species from a 'common pool'. The 31 bivalve species in this study are considered to represent a reasonable species pool however, to propose that all 31 are equally likely to inhabit and to survive at any station in the Beaufort Sea is simplistic. It is important, therefore, to interpret results of the expected species analysis in the light of the assumption of ubiquitous distribution of all species of bivalves.

Table 3 summarizes the results of the compositional similarity test for the shallow-water bivalve fauna of
Beaufort Sea, first by a pairwise comparison of all stations and second by station comparisons partitioned separately by depth and transect. Based on the calculations of expected taxa shared $\left(\mathrm{E}_{\mathrm{ts}}\right)$ (Connor and Simberloff, 1978), $35 \%$ of all pairwise station comparisons had significant numbers of abundant species in common $(\mathrm{P}<.05)$ (Table $3 \mathrm{~A})$. If in $50 \%$ of all pairwise station comparisons the number of observed taxa shared $\left(\mathrm{O}_{\mathrm{ts}}\right)$ is greater than the computed expected value, the null hypothesis should be rejected (Hendrickson, 1981). The majority of stations under study (65\%) contained more observed taxa shared $\left(\mathrm{O}_{\mathrm{ts}}\right)$ than would be expected by chance, and the null hypothesis was rejected by this conservative test $\left(\mathrm{X}^{2}=47.73, \mathrm{P}<\right.$ .005).

To determine whether any one transect or depth can account for the differences between observed and expected species in common, station comparisons were partitioned by depth and transect (Table 3B). In all but 2 of the partitioned analyses the null hypothesis is again rejected. Species in common between stations are greater than expected. For only the $5 \mathrm{~m}$ stations and the Pingok Island transect station comparisons is the null hypothesis not rejected. This result is most likely due to the general trend of small numbers of species and individuals per station, especially at $5 \mathrm{~m}$. Station PPB 05 is an exception and has an anomalously high numerical density and species richness; this result distorts the total number of individuals and total species collected for the $5 \mathrm{~m}$ stations (Table 2). Overall, the distribution of the shallow Beaufort bivalve fauna does not appear to be solely the result of the stochastic persistence and dispersal of equi-probable species from a limited species pool. In all cases there is a 
Table 3. Summary of results obtained under Null Hypothesis I (Connor and Simberloff, 1978). Partitioned analyses (B) are comparisons based on stations from a particular depth or transect (longitude) against all other stations in study area

\begin{tabular}{|c|c|c|c|c|c|c|c|c|}
\hline $\begin{array}{l}\text { Compari- } \\
\text { sons }\end{array}$ & $\begin{array}{l}\text { Total no. } \\
\text { pairwise } \\
\text { comparisons }\end{array}$ & OBS $>$ Exp & $\begin{array}{l}O B S>\operatorname{Exp} \\
(P<.05)\end{array}$ & OBS $<$ EXP & $\begin{array}{l}\text { OBS }<\operatorname{Exp} \\
(P<.05)\end{array}$ & $\begin{array}{l}\text { OBS }=\operatorname{Exp} \\
(P<.05)\end{array}$ & $\begin{array}{l}\text { CHI- } \\
\text { Square }\end{array}$ & $P$ \\
\hline \multicolumn{9}{|c|}{ (A) Total analysis } \\
\hline All stations & 231 & 168 & $81(35 \%)$ & 63 & 0 & $151(65 \%)$ & 47.73 & $<.005$ \\
\hline \multicolumn{9}{|c|}{$\begin{array}{l}\text { (B) Partitioned analyses } \\
\text { By depth }\end{array}$} \\
\hline 5 & 95 & 45 & $17(18 \%)$ & 50 & 0 & $78(82 \%)$ & 0.26 & $>.05$ \\
\hline 10 & 95 & 81 & $44(46 \%)$ & 14 & 0 & $51(54 \%)$ & 47.26 & $<.005$ \\
\hline 15 & 95 & 73 & $30(32 \%)$ & 22 & 0 & $65(68 \%)$ & 27.38 & $<.005$ \\
\hline 20 & 60 & 46 & $24(40 \%)$ & 14 & 0 & $36(69 \%)$ & 17.06 & $<.005$ \\
\hline 25 & 78 & 61 & $26(33 \%)$ & 17 & 0 & $52(67 \%)$ & 24.82 & $<.005$ \\
\hline \multicolumn{9}{|l|}{ By transect } \\
\hline BRB & 95 & 64 & $20(21 \%)$ & 31 & 0 & $75(79 \%)$ & 11.46 & $<.005$ \\
\hline PPB & 95 & 77 & $42(44 \%)$ & 18 & 0 & $53(56 \%)$ & 36.63 & $<.005$ \\
\hline PIB & 60 & 35 & $17(28 \%)$ & 25 & 0 & $43(72 \%)$ & 1.66 & $>.05$ \\
\hline NIB & 78 & 49 & $23(29 \%)$ & 29 & 0 & $45(71 \%)$ & 5.12 & $<.025$ \\
\hline $\mathrm{BAB}$ & 95 & 78 & $43(45 \%)$ & 17 & 0 & $52(55 \%)$ & 29.16 & $<.005$ \\
\hline
\end{tabular}

significant proportion of stations that have more species in common than would be expected under the null hypothesis of random dispersal and survival.

\section{Food source}

A study of feeding types from the inner Beaufort Sea shelf stations was undertaken to attempt to explain this non-random distribution of the coastal bivalves among the stations. We sought insight about faunal-environmental interactions at the inner margin of the marine environment where the gradients of many physical characteristics are generally steep, and we argued that a study of feeding types could yield distributional patterns of a more functional nature than groupings based on taxonomy alone.

Species were classified either as deposit or suspension feeders based on their functional morphology, information from the literature, and direct observation of the gastrointestinal tract contents of the most abundant species. Deposit feeders included all 11 protobranchs and the 4 Macoma species (Table 2). The remaining species were considered suspension feeders; however, feeding behavior for several species, e.g. Axinopsida orbiculata, remains questionable without direct observations. The sedimentary gut contents of Portlandia arctica and Macoma calcarea concurred with data reported in the literature for other members of their respective families (Yonge, 1939, 1949; Brafield and Newell, 1961). Liocyma fluctuosa contained a wide range of food items that was derived from suspension feeding in agreement with Ansell's (1961) findings for other members of the Veneridae.
Our studies demonstrated that Boreacola vadosa, presumably a suspension feeder, had ingested resuspended flocculent material that included juvenile molluscs and terrestrial plant material. This overall classification divided the total number of bivalve species roughly in half (Table 2 ), although over $75 \%$ of all individuals were suspension feeders

The percentages of suspension and deposit feeding species remained relatively constant by depth and transect, but there was a dramatic change in the relative proportions of individuals in suspension and deposit feeding categories with depth (Table 4). The innermost stations with high percent sand (65 to $97 \%$ ) had a higher proportion of suspension feeding individuals $(93 \%)$. Conversely, there was a trend toward greater numbers of deposit feeding bivalves with increasing depth, from $7 \%$ at $5 \mathrm{~m}$ to $85 \%$ at $25 \mathrm{~m}$. Densities of bivalve feeding groups were associated both with depth $\left(\mathrm{X}^{2}=1440.47, \mathrm{P}<.005\right)$ and transect $\left(\mathrm{X}^{2}=186.6, \mathrm{P}<.005\right)$. There was a significantly positive correlation of deposit feeding individuals with increasing depth (Kendall's tau $=0.30, P=.026$ ).

Numerous studies demonstrate the effects of particle size and the resulting properties of sediments on the distribution and abundance of benthic macrofaunal species and feeding types (e.g. Sanders, 1958; Rhoads and Young, 1970; Franz, 1976; Coleman and Cuff, 1978). The shallow-water sediment samples from Beaufort Sea were analysed for percent clay, silt, sand and gravel. Correlations (Kendall's tau) between sediment type and feeding type were calculated. Deposit feeder density was negatively correlated with percent gravel $(\mathrm{P}=.003)$ and with percent sand $(\mathrm{P}=.048)$. Positive correlations were found with deposit feeders 
Table 4. Bivalve feeding types

(A) Percent feeding type by depth and by transect. Based on total number of individuals collected at each station

\begin{tabular}{lccc}
\hline $\begin{array}{c}\text { Depth } \\
(\mathrm{m})\end{array}$ & $\begin{array}{c}\text { Total } \\
\text { \# of indivi- } \\
\text { duals }\end{array}$ & $\begin{array}{c}\text { \% Sus- } \\
\text { pension } \\
\text { feeders }\end{array}$ & $\begin{array}{c}\text { \% Deposit } \\
\text { feeders }\end{array}$ \\
\hline 5 & 2,539 & 93 & 7 \\
10 & 1,030 & 57 & 43 \\
15 & 673 & 70 & 30 \\
20 & 365 & 52 & 48 \\
25 & 410 & 15 & 85 \\
Transect & & & \\
Pt. Barrow & 344 & 76 & 24 \\
Pitt Point & 3,052 & 81 & 19 \\
Pingok Island & 641 & 60 & 40 \\
Narwhal Island & 125 & 67 & 33 \\
Barter Island & 838 & 68 & 32 \\
\hline
\end{tabular}

(B) Percent of species: feeding type by depth and by transect

\begin{tabular}{|cccc}
\hline $\begin{array}{c}\text { Depth } \\
(\mathrm{m})\end{array}$ & $\begin{array}{c}\text { Total } \# \\
\text { of } \\
\text { species }\end{array}$ & $\begin{array}{c}\text { \% Sus- } \\
\text { pension } \\
\text { feeders }\end{array}$ & $\begin{array}{c}\text { \% Deposit } \\
\text { feeders }\end{array}$ \\
\cline { 3 - 4 } 5 & 15 & 80 & 20 \\
10 & 18 & 55 & 45 \\
15 & 20 & 55 & 45 \\
20 & 14 & 36 & 64 \\
25 & 18 & 44 & 56 \\
Transect & & & \\
Pt. Barrow & 12 & 58 & 42 \\
Pitt Point & 20 & 60 & 40 \\
Pingok Island & 16 & 56 & 44 \\
Narwhal lsland & 18 & 56 & 44 \\
Barter Island & 18 & 50 & 50 \\
\hline
\end{tabular}

and percent silt $(\mathrm{P}=.004)$ and clay $(\mathrm{P}=.048)$. No significant correlations between filter feeder density and sediment type were found. Negative correlations were found between percent sand with depth $(\mathrm{P}=.001)$ and positive correlations between depth and percent silt $(\mathrm{P}=.004)$ and between depth and percent clay $(\mathrm{P}=.001)$.

\section{DISCUSSION}

Results indicate that the bivalve fauna of the southwestern Beaufort Sea is broadly distributed throughout the region. There are no strong spatial or depth patterns in overall abundance, species richness, or species composition. However, some of the fauna is reacting to depth-related features as demonstrated by the significant differences in the relative abundance of one of the functional feeding groups by depth.

In a study that involved 76 species of living bivalves and gastropods from a broad depth range (3 to $539 \mathrm{~m}$ ) in the southeastern Beaufort Sea, Wagner (1977) concluded that water depth was the major controlling factor. Specific environmental features that were correlated with depth could not be identified with the techniques used in that study. Of the 10 species within the depth zone of our study that Wagner designated as depth indicators, we collected 3 species: Cyrtodaria kurriana, Macoma calcarea, and Liocyma fluctuosa (Table 2). Depth-related environmental factors on the shallow shelf that control species distributions, therefore, probably extend throughout the Beaufort Sea.

\section{Density and species richness}

In spite of the harsh environment in the Arctic Ocean in the nearshore depth zone sampled, 31 living species of bivalves occur with densities as high as 3,200 individuals $\mathrm{m}^{-2}$ (mean density $300 \mathrm{~m}^{-2}$ ). MacGinitie (1959) reported only 13 species in a comparable depth zone at Point Barrow. Wacasey (1977) sampled 12 species in the 5 to $25 \mathrm{~m}$ zone in the eastern Beaufort Sea, while a study similar to ours in the nearshore western Beaufort ( 4 to $23 \mathrm{~m}$ ) yielded 9 living bivalve species (Hülsemann, 1962). Higher estimates of the species richness were reported by Wagner (1977) who found 27 living bivalve species from 6 to $35 \mathrm{~m}$ in the eastern Beaufort. The most comprehensive report of Beaufort bivalves (Bernard, 1979) reported 20 species at depths of $25 \mathrm{~m}$ or less. In that publication based largely on Oregon State University samples taken in 1971 and 1972 the nearshore region was poorly represented.

Comparison of density and species richness between the exposed Arctic coastline and more temperate coasts is illuminating. The Arctic has a rich bivalve fauna and little wave activity, whereas the shallow zone $(5$ to $25 \mathrm{~m})$ of the northeastern Pacific along the open coasts of northern California, Oregon, and Washington has significant wave activity throughout the year (Clifton et al., 1971; Sternberg and McManus, 1972) and supports a limited bivalve fauna. Nelson et al. (1981) report bivalve species from Oregon in densities generally less than $240 \mathrm{~m}^{-2}$. Lie and Kisker (1970) sampled 5 species in shallow water off the Olympic Peninsula, Washington. The above areas were found to have an homogeneous sediment structure of over $95 \%$ sand. Boesch (1972) reported similar low diversity along the open coast of Virginia. The habitat in this region was predominately coarse sands and shell material which was subject to intense wave activity. Boesch (1972) compared his findings in Virginia to those of Lie and Kisker (1970) on the open Washington coast. He also agreed that the macrobenthos was 'predominately physically controlled by wave 
energy' in both areas. Persson (1983) reported 6 bivalves species off the open coast of the southern Baltic Sea and concluded that reduced species numbers at $5 \mathrm{~m}$ depth 'might be due to increased exposure'. Wave height in the southern Baltic Sea is generally less than $3 \mathrm{~m}$, and wave-induced bottom turbulence affects sediments to water depths of $6 \mathrm{~m}$.

Protected marine waters with heterogeneous and finer sediments generally harbor more species of bivalves than shallow, open-coast habitats. Sanders (1958) reported 10 species of bivalves in Buzzards Bay, Massachusetts, at water depths of 10 to $20 \mathrm{~m}$ in muddy to sandy sediments. Lie (1968) occupied 4 stations with depths between 9 and $25 \mathrm{~m}$ in sheltered environments of Puget Sound, Washington where sediments were predominately fine sands. Forty bivalve species were identified from these Puget Sound stations, with average densities of 560 individuals $\mathrm{m}^{-2}$.

\section{Compositional similarity - feeding type}

Bivalve species distributions in the SW Beaufort Sea have higher similarities than one would expect by random associations (Table 3). There is a pattern of distribution based on feeding adaptations that appears to exist in the nearshore Arctic bivalves. Numbers of deposit-feeding species and individuals increase with increased silt and clay. Correspondingly, from 5 to $25 \mathrm{~m}$ depths, silt and clay percentages tend to increase, although sediment types tend to be patchy in distribution. The data suggest that the increase in silt and clay fractions of sediment at the deeper stations supports the greater proportion of deposit-feeding bivalves there (Sanders, 1958). Suspension feeders constitute the major proportion of bivalves in shallow, sandy stations, although no statistically significant correlations were found. The sediment patchiness may partially explain the lack of general station grouping by depth. Hickman and Nesbitt (1980) found similar distributional patterns over a wider depth range for the molluscs of the Gulf of Alaska. As the depth and silt/ clay percentages increased they reported a decrease in the proportion of suspension feeders and an increase in the proportion of deposit feeding, protobranch bivalves.

The changes in bivalve assemblages of the southwestern Beaufort Sea are trends rather than the sharp species zonations reported by Field (1971), Massé (1972), and Oliver et al. (1980) for shallow coastal regions. In these latter studies the environmental gradient included the transitional zone between the turbulent surf and the less energetic continental shelf beyond reach of average surface waves. Vagile species were replaced by tube dwellers and burrowers in deeper water (Oliver et al., 1980). In the southwestern Beaufort Sea there is a gradient in sediment particle size, though it appears less marked and the transition zone narrower and shallower along the open Arctic coast than off the open west coast of the continental United States (Oliver et al., 1980; Hogue, 1982).

The diminished and infrequent wave disturbance of the nearshore Beaufort Sea is likely to be a major cause of the broad distributions and the lack of clear vertical zonation of the bivalve species. Wave-generated bottom turbulence has been deduced as an explanation for patterns of distribution and abundance in the innermost shelf environment for megabenthos (Davis and VanBlaricom, 1978), macrobenthos (Day et al., 1971; Field, 1971; Christie, 1976; Rees et al., 1976; McCall, 1977; Oliver et al., 1980), and meiobenthos (Hogue, 1982). The data of Oliver et al. (1980) suggest that sediment instability is caused by wave turbulence off northern California. However, in the Beaufort Sea the decrease in species richness at $5 \mathrm{~m}$ is probably caused by run-off and ice-related stress rather than wave action.

The above statistical analyses have demonstrated that the 31 species of bivalve molluscs studied on the inner southwestern Beaufort Sea shelf are generally distributed from 5 to $25 \mathrm{~m}$ depth. We suggest that MacGinitie's hypothesis for uniform species distributions is upheld in this nearshore environment and that its explanation is low wave turbulence. It remains to be seen whether other major taxa are also distributed broadly in this transitional zone. Beyond this shallow environment there is a tendency for sublittoral megafaunal and macrofaunal species to have broad depth distributions across the shelf, but benthic species groups can be assigned to depth zones (Carey et al., 1974; Carey and Ruff, 1977; Bilyard and Carey, 1979). Beyond shelf depths the vertical distributions of species become narrower and there is a strong correlation with depth. Therefore, MacGinitie's 'unit environment' is likely to be found only on the inner continental shelf.

\section{CONCLUSIONS}

An abundant and diverse assemblage of bivalve molluscs was found along the nearshore Arctic shelf. The number of bivalve species appears to remain uniform throughout the region sampled; therefore, MacGinitie's hypothesis was upheld for the coastal bivalve molluscs.

The majority of stations contained more species in common than would be expected by chance alone; thus, the distribution of bivalve species does not appear to be the result of stochastic persistence.

Analysis of functional feeding groups yielded dis- 
tributional patterns related to depth and sediment type. Proportionally more deposit-feeding bivalves live at the deeper stations which are correlated with increased silt-clay fractions in the sediment.

Species richness and numerical density are higher on the Arctic inner shelf than at similar depths on temperature open coastal environments. Diminished bottom turbulence caused by low surface wave activity is a possible explanation for this phenomenon.

Acknowledgements. We thank P. A. Montagna for assistance in the laboratory and field, and R. E. Ruff and L. Yee-Downs for assistance in the laboratory. F. Bernard and E. V Coan aided in taxonomic matters, and $\mathrm{S}$. Naidu analysed the sediments. E. W. Hogue, R. E. Ruff, G. Braun, E. V. Coan, F. G. Hochberg, J. N. Nybakken, B. Profant, B. Roth, C. B. Miller, and W. G. Pearcy contributed helpful comments during development of the manuscript. We acknowledge the kind assistance of the officers and crew of $R / V$ 'Alumiak' and USCGC 'Glacier'. This study was funded by the Bureau of Land Management through interagency agreement with the National Oceanic and Atmospheric Administration as part of the Outer Continental Shelf Environmental Assessment Program.

\section{LITERATURE CITED}

Anderberg, M. R. (1973). Cluster analysis for applications. Academic Press, New York

Ansell, A. D. (1961). The functional morphology of the British species of Veneracea (Eulamellibranchia). J. mar biol. Ass. U.K, $41: 489-515$

Barnes, P. W., Reimnitz, E. (1974). Sedimentary processes on Arctic shelves off the northern coast of Alaska. In: Reed, J. C., Sater, J. E. (ed.) The coast and shelf of the Beaufort Sea. Arctic Inst. North America, Arlington, Virginia, p. 439476

Barnes, P. W., McDowell, D. M., Reimnitz, E. (1978). Ice gouging characteristics: their changing patterns from 1975-1977, Beaufort Sea, Alaska. U.S. Geol. Surv. OpenFile Rep. 78-730

Bernard, F. R. (1979). Bivalve molluscs of the western Beaufort Sea. Contrib. Sci. Natur. Hist. Mus. Los Angeles County No. 313: 1-80

Bilyard, G. R., Carey, A. G., Jr. (1979). Distribution of western Beaufort Sea polychaetous annelids. Mar Biol. 54: 329-339

Boesch, D. F. (1972). Species diversity of marine macrobenthos in the Virginia area. Chesapeake Sci. 13: 206-211

Brafield, A. E., Newell, G. E. (1961). The behaviour of Macoma balthica (L.). J. mar. biol. Ass. U.K. 41: 81-87

Carey, A. G., Jr., Ruff, R. E., Castillo, J. G., Dickinson, J. J. (1974). Benthic ecology of the western Beaufort Sea continental margin: Preliminary results. In: Reed, J. C., Sater, J. E. (ed.) The coast and shelf of the Beaufort Sea. Arctic Inst. North America, Arlington, Virginia, p. 665-680

Carey, A. G., Jr., Ruff, R. E. (1977). Ecological studies of the benthos in the western Beaufort Sea with special reference to bivalve molluscs. In: Dunbar, M. J. (ed.) Polar Oceans. Arctic Inst. North America, Calgary, Alberta, p. 505-530

Christie, N. D. (1976). A numerical analysis of the distribution of a shallow sublittoral sand macrofauna along a transect at Lamberts Bay, South Africa. Trans. R. Soc. S. Afr, 42 : $149-172$
Clifton, H. E., Hunter, R. E., Phillips, R. L. (1971). Depositional structures and processes in the non-barred high-energy nearshore. J. Sed. Petrol. 41: 651-670

Coleman, N., Cuff, W. (1978). The abundance, disribution and diversity of the molluscs of Western Port, Victoria, Australia. Malacologia 20: 35-62

Connor, E. F., Simberloff, D. (1978). Species number and compositional similarity of the Galapagos flora and avifauna. Ecol. Monog. 48: 219-248

Dall, W. H. (1919). The molluscs of the Arctic coast of America collected by the Canadian Arctic Expedition west from Bathurst Inlet with an appended report on a collection of Pleistocene fossil Mollusca. Rep. Canadian Arctic Exped. 1913-1918. 8 (A): 3 A-35 A

Davis, N., van Blaricom, G. R. (1978). Spatial and temporal heterogeneity in a sand bottom epifaunal community of invertebrates in shallow water. Limnol. Oceanogr. 23: $417-427$

Day, J. H., Field, J. G., Montgomery, M. P. (1971). The use of numerical methods to determine the distribution of the benthic fauna across the continental shelf of North Carolina. J. Anim. Ecol. 40: 93-125

Eisma, D. (1966). The distribution of benthic marine molluscs off the main Dutch coast. Netherlands J. mar. Res. 3: $107-163$

Field, J. G. (1971). A numerical analysis of changes in the soft-bottom fauna along a transect across False Bay, South Africa. J. exp. mar. Biol. Ecol. 7: 215-253

Franz, D. (1976). Benthic molluscan assemblages in relation to sediment gradients in northwestern Long Island Sound, Connecticut. Malacologia 15: 377-399

Gage, J. (1974). Shallow-water zonation of sea loch benthos and its relation to hydrographic and other physical features. J. mar biol. Ass. U.K. 54: 223-249

Harper, C. W., Jr. (1978). Groupings by locality in community ecology and paleoecology: tests of significance. Lethaia 11: 251-2.57

Heck, K. L., Jr., van Belle, G., Simberloff, D. (1975). Explicit calculation of the rarefaction diversity measurement and the determination of sufficient sample size. Ecology 56 : $1459-1461$

Hendrickson, J. A., Jr. (1981). Community-wide character displacement reexamined. Evolution 35: 794-809

Hickman, C. S., Nesbitt, E. A. (1980). Holocene mollusk distributional patterns in the northern Gulf of Alaska. In: Field, M. E. et al. (ed.) Quaternary depositional environments of the Pacific coast, Pacific coast paleogeography symposium 4. Soc. Ecen, Paleontol. Mineral., Los Angeles, California, p. 305-312

Hogue, E. W. (1982). Sediment disturbance and the spatial distributions of shallow water meiobenthic nematodes on the open Oregon coast. J. mar. Res. 40:551-573

Hülsemann, K. (1962). Marine pelecypoda from the north Alaskan coast. Veliger 5: 67-73

Hurlbert, S. H. (1971). The nonconcept of species diversity: a critique and alternative parameters. Ecology 52: 577-586

Jaccard, P. (1908). Nouvelle recherche sur la distribution floral. Bull. Soc. Vandoise Sci. Nat. 44: 223-270

Jumars, P. A. (1976). Deep-sea species diversity: does it have a characteristic scale? J. mar. Res. 34: 217-246

Kovacs, A., Mellor, M. (1974). Sea ice morphology and ice as a geologic agent in the southern Beaufort Sea. In: Reed, J. C., Sater, J. E. (ed.) The coast and shelf of the Beaufort Sea. Arctic Inst. North America. Arlington, Virginia, p. 113-161

Lie, U. (1968). A quantitative study of benthic infauna in Puget Sound, Washington, USA, in 1963-64. FiskDir. Skr. Ser. HavUnders 14: 229-556 
Lie, U., Kisker, D. S. (1970) Species composition and structure of the benthic infauna communities off the coast of Washington. J. Fish. Res. Bd Can. 27: 2273-2285

McCall, P. L. (1977). Community patterns and adaptive strategies of the infaunal benthos of Long Island Sound. J. mar. Res. 35: 221-266

MacGinitie, G. E. (1955). Distribution and ecology of the marine invertebrates of Point Barrow, Alaska. Smithsonian Misc. Collect. 128 (9): 1-201

MacGinitie, N. (1959). Marine Mollusca of Point Barrow, Alaska. U.S. Nat. Mus. Proc. 109: 59-298, pls 1-27

Massé, H. (1972). Quantitative investigations of sand-bottom macrofauna along the Mediterranean north-west coast. Mar. Biol. 15: 209-220

Matthews, J. B. (1971). Long period gravity waves and storm surges on the Arctic Ocean continental shelf. Proc. Joint Oceanogr. Assembly, Tokyo 1970

Matthews, J. B. (1980). Characterization of the nearshore hydrodynamics of an arctic barrier island-lagoon system. In: Environmental assessment of the Alaskan continental shelf, annual reports of principal investigators, March 1980. Vol. VI. NOAA, Boulder, Colorado, p. 577-601

Mountain, D. G. (1974). Preliminary analysis of Beaufort shelf circulation in summer. In: Reed, J. C., Sater, J. E. (ed.) The coast and shelf of the Beaufort Sea. Arctic Inst. North America, Arlington, Virginia, p. 27-48

Nelson, P. O., Sollitt, C. K., Williamson, K. J., Hancock, D. R. (1981). Coos Bay offshore disposal site investigation. Interim Rpt. U.S. Army Corps Engineers. Contract No. DACW57-79-C0040

Oliver, J. S., Slattery, P. N., Hulberg, L. W., Nybakken, J. W. (1980). Relationship between wave disturbance and zonation of benthic invertebrate communities along a subtidal high-energy beach in Monterey Bay, California. Fish. Bull. U.S. 78: $437-454$

Pearson, T. H. (1970). The benthic ecology of Loch Linnhe and Loch Eil, a sea-loch system on the west coast of Scotland. $I$. The physical environment and distribution of macrobenthic fauna. J. exp. mar. Biol. Ecol. 5: 1-34

Peet, R. K. (1974). The measurement of species diversity. Ann. Rev. Ecol. Syst. 5: 285-307

Persson, L.-E. (1983). Temporal and spatial variation in coastal macrobenthic community structure, Hano Bay (Southern Baltic). J. exp. mar. Biol. Evol. 68: 277-293

Raup, D. M., Crick, R. E. (1979). Measurement of faunal similarity in paleontology. J. Paleontology 53: 1213-1227

Rees, E. I. S., Nicholaidou, A., Laskaridou, P. (1976). The effects of storms on the dynamics of shallow water benthic assocations. In: Keegan, B. F., Ceidigh, P. O., Boaden, P. J. S. (ed.) Biology of benthic organisms. Pergamon Press, Oxford, p. 465-474

Reimnitz, E., Barnes, P. W. (1974). Sea ice as a geologic agent on the Beaufort Sea shelf of Alaska. In: Reed, J. C., Sater, J. E. (ed.) Arctic Inst. North America, Arlington, Virginia, p. 301-353
Rhoads, D. C., Young, D. K. (1970). The influence of depositfeeding organisms on sediment stability and community trophic structure. J. mar. Res. 28: 150-178

Sanders, H. L. (1958). Benthic studies in Buzzards Bay. I. Animal sediment relationships. Limnol. Oceanogr. 3: $245-258$

Sharma, G. D. (1979). The Alaskan shelf. Springer-Verlag, New York

Short, A. D., Coleman, J. M., Wright, L. D. (1974). Beach dynamics and nearshore morphology of the Beaufort Sea coast, Alaska. In: Reed, J. C., Sater, J. E. (ed.) The coast and shelf of the Beaufort Sea. Arctic Inst. North America, Arlington, Virginia, p. $477-488$

Simberloff, D. (1978). Using island biogeographic distributions to determine if colonization is stochastic. Am. Nat. 112: 713-726

Simberloff, D. S., Conner, E. F. (1980). Q-mode and R-mode analyses of biogeographic distributions: null hypotheses based on random colonization. In: Patil, G. P., Rosenzweig, M. L. (ed.) Contemporary quantitative ecology and related econometrics. Internat. Co-op. Publ. House, Fairland, Maryland, p. 123-138

Smith, W., McIntyre, A. D. (1954). A spring-loaded bottom sampler. J. mar. biol. Ass. U.K. 33: 257-264

Squire, V. A., Moore, S. C. (1980). Direct measurement of the attenuation of ocean wave by pack ice. Nature, Lond. 283: 365-368

Sternberg, R. W., McManus, D. A. (1972). Implications of sediment dispersal from long-term, bottom-current measurements on the continental shelf of Washington. In: Swift, D. J. P., Duane, D. B., Pilkey, O. H. (ed.) Shelf sediment transport: process and pattern. Dowden, Hutchinson and Ross, Inc. Stroudsberg, Pennsylvania, p. 181-194

Wacasey, J. W. (1975). Biological productivity of the southern Beaufort Sea: zoobenthic studies. Canada Dept. Environ. Beaufort Sea Proj. Tech. Rep. 12B

Wacasey, J. W. (1977). Zoobenthos data from the southem Beaufort Sea. Canadian Dept. Fish. Environ., Fish. Mar. Service Data Rep. No. 41

Wagner, F. J. E. (1977). Recent mollusc distribution patterns and paleobathymetry, southeastern Beaufort Sea. Can. J. Earth Sci. 14: 2013-2028

Wiseman, W. J., Jr., Suhayda, J. N., Hsu, S. A., Walters, C. D., Jr. (1974). Characteristics of nearshore oceanographic environment of Arctic Alaska. In: Reed, J. C., Sater, J. E. (ed.) The coast and shelf of the Beaufort Sea. Arctic Inst. North America, Arlington, Virginia, p. 49-64

Yonge, C. M. (1939). The protobranchiate Mollusca: a functional interpretation of their structure and evolution. Phil. Trans. R. Soc. Lond. (B) 230: 79-147

Yonge, C. M. (1949). On the structure and adaptations of the Tellinacea, deposit-feeding Eulamellibranchia. Phil. Trans. R. Soc. Lond. (B) 234: 29-76 